УДК $316.6(075)$

DOI: 10.37026/2520-6427-2021-107-3-91-95

\section{Борис САВЧУК,}

доктор історичних наук, професор, професор кафедри педагогіки та освітнього менеджменту імені Богдана Ступарика

Прикарпатського національного університету імені Василя Стефаника,

м. Івано-Франківськ, Украйна

ORCID 0000-0003-2256-0845

e-mail:boris_savchuk@ukr.net

\section{Віра КОВАЛЬЧУК,}

кандидат педагогічних наук, доцент,

доцент кафедри педагогіки

та освітнього менеджменту

імені Богдана Ступарика

Прикарпатського наиіонального університету

імені Василя Стефаника,

м. Івано-Франківськ, Украӥна

ORCID 0000-0002-1292-6500

e-mail:vira1959@i.ua

\title{
ФОРМУВАННЯ КОНФЛІКТОЛОГІЧНОЇ КОМПЕТЕНТНОСТІ МАЙБУТНІХ ПЕДАГОГІВ ЯК СКЛАДНИКА ПЕДАГОГІЧНОЇ МАЙСТЕРНОСТІ
}

\begin{abstract}
Анотація. У статті обтрунтовано потребу зміни акцентів у формуванні конфліктологічної компетентності майбутніх педагогів як складової педагогічноі майстерності. Доведено, щзо сучасний освітній процес наскрізь просякнутий суперечностями, конфліктними ситуачіями і глибокими затяжними конфліктами, які варто сприймати не як «апріорі зло», а як природні й певною мірою закономірні прояви міжособистісних стосунків. Зважаючи на ие, в розвитку конфліктологічної компетентності необхідно змінити пріоритети зі спрямування зусиль на запобігання, профілактику виникнення конфліктів, формування культури поведінки в конфліктних ситуаціях та знань, умінь $і$ навичок щзодо ефективного розв 'язання конфліктів, мінімізащії їхніх деструктивних провів.

У формуванні конфліктологічної компетентності як складника педагогічної майстерності майбутнього фахівия виокремлено два блоки: 1) особистісний,
\end{abstract}

щзо передбачає розвиток емпатії; інтелектуальної гнучкості; педагогічного такту; креативності; духовності, відкритості, етичності; саморефлексії, самоаналізу; 2) професійнии - акиентує увагу на тому, щзо оволодіння теоретичними знаннями про феномен педагогічного конфлікту передбачає усвідомлення їхньої постійної модернізації на засадах плюралізму, контроверсійності, нелінійності, щуо виявлясться в трактуванні терміносистеми, яка визначає феномен педагогічного конфлікту та його структурні компоненти. Актуалізовано потребу використання зарубіжного досвіду формування конфліктологічної компетентності педагогів, щзо трунтується на принципах культурного плюралізму, терпимості.

Ключові слова: конфліктологічна компетентність, міжособистісний конфлікт, педагогічна майстерність, підготовка майбутніх фахівців, освітній проиес.

\section{Borys SAVCHUK,}

Doctor of Historical Sciences, Professor,

Professor of B. Stuparyk Department of Pedagogy and Educational Management,

Vasyl Stefanyk Precarpathian National University,

Ivano-Frankivsk, Ukraine

ORCID 0000-0003-2256-0845

e-mail:boris_savchuk@ukr.net

Vira KOVALCYUK,

Candidate of Pedagogical Sciences, Associate Professor, B. Stuparyk Department of Pedagogy

and Educational Management,

Vasyl Stefanyk Precarpathian National University,

Ivano-Frankivsk, Ukraine

ORCID 0000-0002-1292-6500

e-mail:vira1959@i.ua 


\section{FORMATION OF CONFLICTOLOGICAL COMPETENCE AS A COMPONENT OF PEDAGOGICAL PROFICIENCY OF FUTURE TEACHERS}

\begin{abstract}
The article substantiates the need to change the emphasis in the formation of conflict competence of future professionals as an important component of their pedagogical skills. It turns out that the modern educational process is permeated with contradictions, conflict situations and deep protracted conflicts, which should be perceived not as «a priori evil», but as natural and to some extent natural manifestations of interpersonal relationships. Therefore, in the development of conflict competence should change priorities to focus on prevention, prophylaxis, warning of conflicts, the formation of a culture of behavior in conflict situations and knowledge, skills, abilities to effectively resolve conflicts, minimize their destructive manifestations.
\end{abstract}

In the formation of conflict competence as an important component of pedagogical skills of the future specialist, two main blocks are identified and characterized. The first block «Personal» involves the development of such qualities as empathy, intellectual and emotional flexibility, pedagogical tact, creativity, spirituality, openness, ethics, self-reflection, self-analysis, self-development. The second «Professional» block emphasizes that mastering theoretical knowledge about the phenomenon of pedagogical conflict should involve awareness of their constant modernization on the basis of pluralism, controversy, multifacetedness, nonlinearity. This is manifested in the interpretation of the terminology that defines the phenomenon of pedagogical conflict and its structural components. With such a statement of the problem, the need to use innovative foreign experience (theoretical approaches, practical methods and techniques, etc.) to form the conflictological competence of future teachers, built on the principles of pluralism, ideological diversity, tolerance.

Key words: conflictological competence, interpersonal conflict, pedagogical skill, training of future specialists, educational process.

Постановка проблеми. Означена в назві статті проблема відзначається науково-теоретичною актуальністю, практичною значущістю та посідає вагоме місце в українському і зарубіжному психолого-педагогічному дискурсі. До ії з'ясування підходимо у двох взаємопов'язаних ракурсах. Перший - термінологічний - відображає палітру підходів і трактувань феноменів «педагогічна майстерність» $\mathrm{i}$ «кофліктологічна компетентність» та пов'язаних із ними дефініцій. Їхній інтерпретації присвячено значний масив публікацій, що становить основу для предметного аналізу другого ракурсу - науково-педагогічного дискурсу, який стосується підходів до формування конфліктологічної компетентності майбутніх фахівців. Ідеться про одну зі стрижневих, з нашого погляду, дилем, що стосується перенесення акцентів із формування в майбутніх учителів знань, умінь, навичок щодо попередження і запобігання виникнення конфліктів між учасниками освітнього процесу (студентами, науково-педагогіч- ними працівниками, представниками адміністрації) на випрацювання досвіду оптимальної поведінки в конфлікті та здатності його продуктивно розв'язати. Науково-теоретичною основою реалізації такого підходу є формування нового розуміння сутності соціальних і міжособистісних, зокрема педагогічних, конфліктів як природних і значною мірою закономірних супутників розвитку освітнього процесу та соціальних і професійних стосунків.

Аналіз наукових досліджень і публікацій. Тема дослідження перебуває на перетині вивчення фундаментальних проблем педагогічної науки, відображених у значному масиві студій. Це стосується праць, які дають розуміння педагогічної майстерності як синтезу наукових знань, умінь і навичок педагогічної майстерності та особистих якостей, необхідних для розвитку конфліктологічної культури майбутнього фахівця (А. Астахова, Дж. Брунер, І. Зязюн, О. Капченко, Н. Кардаш, Ю. Кузьменко, А. Кузьмінський, Б. Кобзар, В. Луговий, В. Мадзігон, Т. Матвійчук, В. Олійник, I. Синиця, Н. Слюсаренко, В. Сухомлинський, Е. Торенс, Л. Чумак та ін.). Інша група студій окреслює рецепцію сутності, особливостей, підходів до розв'язання педагогічних конфліктів (Ф. Василюк, Л. Воробйов, О. Гречановська, Т. Драгунов, Н. Грішина, В. Журавльов, І. Козич, Н. Кошечко, К. Левітан, С. Ледер, Л. Мітіна, М. Мосьпан, Б. Хасан та ін.). Утім у задекларованому нами вигляді питання формування конфліктологічної компетентності як складника педагогічної майстерності майбутнього фахівця не стало предметом спеціального наукового аналізу.

Мета статті - схарактеризувати необхідність зміни парадигми конфліктологічної компетентності майбутнього фахівця, який у реалізації своєї педагогічної майстерності має зосереджуватися не так на запобіганні виникненню конфліктів, як на формуванні в здобувачів освіти особистісного досвіду і культури поведінки в конфліктних ситуаціях.

Виклад основного матеріалу дослідження. 3 огляду на представлену в наукових студіях палітру дефініцій педагогічної майстерності (Капченко, 2015; Кузьменко, 2018; Педагогічна майстерність, 2008 та ін.), у ракурсі нашого дослідження розглядаємо цей феномен як: характеристику високого рівня педагогічної діяльності, що відповідає критеріям гуманності, науковості, педагогічної доцільності, результативності, демократичності, творчості (оригінальності); складну, багатогранну і гомоморфну систему, яку можна змоделювати з метою її глибшого пізнання; комплекс властивостей особистості, що забезпечують продуктивну професійну діяльність на рефлексивній основі; високий рівень професійної підготовки педагога, що зовні виявляється в успішному творчому розв'язанні різноманітних педагогічних завдань та ефективному досягненні способів і цілей навчально-виховної роботи, а внутрішньо виступає як функційна система знань, 
умінь, навичок, психічних процесів, властивостей особистості, які забезпечують виконання професійних завдань; комплекс спеціальних знань, умінь, навичок і професійно важливих якостей, що уможливлюють ефективну організацію навчально-пізнавальної діяльності здобувачів освіти та здійснення цілеспрямованого педагогічного впливу.

Отже, на нашу думку, саме творчість, креативність, гнучкість, готовність і здатність діяти в різних стандартних і непередбачуваних ситуаціях, глибоке знання психофізіологічних особливостей здобувачів освіти, природи й закономірностей функціонування учнівських, студентських і педагогічних колективів, з одного боку, та висока морально-психологічна, емоційна і стресогенна стійкість педагога, з іншого, є тими стрижнями професійної майстерності, які дають змогу обирати оптимально-правильні шляхи формування конфліктологічної компетентності здобувачів освіти, а також самовдосконалюватися в розвитку відповідних знань, умінь, досвіду.

У спеціальних студіях конфліктологічну компетентність розглядають як складник соціально-психологічної компетентності (О. Анцупов, О. Богданова, У. Мастенбрук, Н. Самсонова, В. Цой та ін.); компонент комунікативної компетентності (Л. Петровська та ін.); різновид професійної компетентності, що пов'язана із соціально-перцептивною, ауто-психологічною, адміністративно-правовою, психолого-педагогічною компетентностями тощо. Так само широкий спектр рефлексій відображає сутність, зміст, структуру, інші базові характеристики конфліктологічної компетентності (С. Баникіна, Н. Грішина, О. Гречановська, В. Журавльов, О. Єфимова, І. Козич, Б. Хасан, С. Філь та ін.). Синтез наукового досвіду в ракурсі нашого дослідження орієнтує на визначення конфліктологічної компетентності майбутнього фахівця як здатності ефективно взаємодіяти 3 оточенням у системі міжособистісних стосунків та розуміти природу суперечностей і міжособистісних конфліктів; володіння навичками неконфліктного спілкування в різних ситуаціях, що виникають у професійній діяльності та міжособистісних стосунках, уміння їх адекватно і правильно сприймати, аналізувати, оцінювати; володіння навичками координації процесу комунікації та вміннями налагоджувати і розвивати конструктивний діалог, зважаючи на різні позиції, погляди, інтереси його учасників. Особливо значущими у формуванні конфліктологічної компетентності є знання, вміння, здатність конструктивно регулювати суперечності та полагоджувати конфліктні ситуації, прогнозувати їхні позитивні й негативні наслідки, орієнтуватися в соціальних ситуаціях, правильно визначати особистісні особливості й емоційні стани інших людей, обирати адекватні способи поводження з ними і реалізовувати їх у процесі взаємодії.

За сучасних умов, що диктують пріоритети діалогічних стосунків, демократичного стилю спілкування, випрацювання індивідуальної траєкторії навчання i розвитку майбутнього фахівця, особливого значення у формуванні конфліктологічної компетентності набуває здатність трансформувати деструктивні стосунки та різного штибу суперечності в конструктивне русло. У цьому випадку випрацювання нового розуміння природи конфліктів і норм взаємодії забезпечує створення умов для виходу із конфліктних ситуацій на якісно новий рівень стосунків та використання такого досвіду для саморозвитку, нарощування інтелектуального потенціалу, вдосконалення емоційно-психологічного стилю поведінки. На нашу думку, зважаючи на сучасні суспільні реалії та впровадження діалогічної, особистісно орієнтованої моделі взаємин учасників освітнього процесу, пріоритетом формування конфліктологічної компетентності майбутнього фахівця має стати продуктивне розв'язання дилеми, що визначає ставлення до самого конфлікту, розуміння його природи, закономірностей виникнення, протікання і наслідків для професійної діяльності та соціальних стосунків. Сутність цієї дилеми полягає у відмові від сприйняття конфлікту як апріорі негативного явища, виникненню якого варто всіляко запобігати. Натомість необхідно формувати розуміння того, що конфлікти є природним і до певної міри закономірним проявом міжособистісних стосунків, тому основну увагу передусім варто зосереджувати на випрацюванні правильної поведінки в конфліктних ситуаціях та формуванні продуктивного життевого досвіду розв'язання конфліктів.

На перетині XX - XXI ст. проблема конфліктів у психолого-педагогічній науці набула фундаментального значення. Розпочався перегляд поширеного у 80-х рр. ХХ ст. «негативістського» підходу до розуміння природи соціальних конфліктів, який акцентував на їхній деструктивній сутності та наслідках (Г. Дойч, М. Джонсон, М. Фішер та ін.).

До перегляду таких теорій спричинився відомий американсько-канадський культуролог, засновник так званої критичної педагогіки Г. Жіру. Закликаючи відмовитися від теорій «гегемонії безконфліктності», вчений стверджував, що через намагання утвердити консенсус у стосунках з учнями учителі ставили критику конфлікту в центр своїх педагогічних моделей. Натомість вони мають виступати арбітрами в таких суперечностях та стосунках між самими учнями й таким чином розвивати досвід конфліктологічної поведінки і культури в себе та своїх вихованців (цит. за: GutierezSchmich, 2016, p. 30-32).

Зважаючи на такі рефлексії Г. Жіру, американська дослідниця Т. Гутьєрез-Шмич під кутом вивчення проблеми «різних ідентичностей» як джерела конфліктогенності в студентському середовищі університетів США концептуалізувала важливі аспекти західної рецепції педагогічної конфліктології. Вона стверджує, що більшість теорій і стратегій розв'язання конфліктів спрямовані на «заспокоєння клімату» в освітньому середовищі, тому вони часто не забезпечують соціальних змін. Учена розкрила домінуючий підхід, згідно з яким конфлікт розглядають як «зло», винятково негативне явище, якого варто «усіляко уникати, а не використовувати як можливість». 3 огляду на те, що конфлікти між викладачами та студентами відбуваються на різних рівнях та в різних «антирепресивних контекстах», вони зазвичай сприймаються як «негативний досвід», тож основні зусилля спрямовуються на їхнє запобігання й усунення. Тому й основні зусилля вчених-теоретиків та педагогів-практиків зосереджені на розробці відповідних стратегій і методик (Gutierez-Schmich, 2016, p. 30-32). 
Синтезувавши широкий спектр поглядів на конфлікти, які мають місце в процесі професійної підготовки молоді в університетах США, Т. Гутьєрез-Шмич стверджує, що вони «природні», адже «присутні щоразу, коли ми беремо участь у важливому проєкті», зокрема й такому, як навчання студентів. Однак слід розрізняти конфлікти як «прості аргументи», що закономірно супроводжують робочий процес, та конфлікти на ідеологічному і політичному грунті, що спричинені проявами расизму, сексизму, гомофобіі, іншими формами системного пригнічення (Gutierez-Schmich, 2016, p. 29-30).

Дещо подібне бачення проблеми артикулюється в пострадянському науково-педагогічному та освітньому просторі (Гречановська, 2018; Козич, 2008; Хасан, 2003 та ін.), проте воно залишається фрагментарним, невиразним, нескристалізованим, тому в теоретичних та експериментальних психолого-педагогічних дослідженнях продовжують домінувати постулати щодо потреби зосередження основних зусиль на розробці програм і стратегій «попередження», «запобігання», «профілактики» виникненню конфліктів.

Зважаючи на означені вище підходи й рефлексії досліджуваних феноменів, визначаємо й обгрунтовуємо основну ідею цього дослідження. Сучасний освітній процес і соціальні стосунки наскрізь просякнуті суперечностями та конфліктними ситуаціями, які часто переростають у складні, глибокі, затяжні конфлікти, тому формування конфліктологічної компетентності

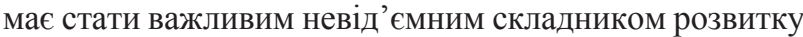
педагогічної майстерності майбутнього фахівця. Пріоритетним вектором формування цієї компетентності повинна бути зміна вектора основних педагогічних зусиль: замість їхнього спрямування на запобігання i попередження виникненню конфліктів основну увагу варто зосередити на формуванні культури поведінки в конфліктних ситуаціях та знань, умінь, навичок щодо ефективного розв'язання конфліктів. Отже, якщо конфлікти є значною мірою об'єктивним явищем у розвитку освітнього процесу, якого не можна уникнути, тоді необхідно зосередити зусилля на мінімізації їхніх деструктивних проявів та формуванні в учнів і студентів культури поведінки в конфлікті й продуктивного досвіду їхнього розв'язання.

Сприймаємо поширений у науковій літературі підхід, згідно з яким у формуванні педагогічної майстерності виокремлюються два взаємопов'язані блоки - особистісний і професійний (Капченко, 2015; Кузьменко, 2018; Педагогічна майстерність, 2008 та ін.). Екстраполюючи цей підхід у русло нашого дослідження, вважаємо, що у формуванні конфліктологічної компетентності майбутнього вчителя як складника його професійної майстерності доцільно зосередитися на формуванні таких особистісних якостей: емпатії, яку розуміємо не лише як прояв співпереживання і співчуття, а й намагання «поставити себе на місце свого опонента», щоб зрозуміти, оцінити, урахувати його інтереси, прагнення, бажання; інтелектуальної й емоційної гнучкості, що передбачає адекватну реакцію на чергові виклики й непередбачувані події, швидку адаптацію (прилаштування) до нових умов, постійний самоконтроль над власними емоціями в конфліктних ситуаціях, здатність до швидкого відновлення емоційного стану в постконфліктній ситуації, розуміння і врахування психічного стану опонента в процесі комунікації; педагогічного такту як універсального вияву стилю спілкування педагога та показника його професійної культури й майстерності, що реалізується через мову і стиль поведінки. Як компонент конфліктної компетентності він передбачає володіння вміннями знаходити доцільні й ефективні способи впливу, здатність швидко реагувати й адекватно оцінювати ситуацію, знаходити оптимальне рішення. Педагогічний такт передбачає уміннями зберігати самовладання і врівноваженість у поєднанні 3 принциповістю і вимогливістю, чуйним ставленням до соціального оточення, скромність, недопущення пихатості й неповаги до інших; креативність як компонент педагогічної майстерності, що означає не лише пошук різних шляхів, способів, засобів розв'язання конфлікту, а й відмову від шаблонів, формалізму, консерватизму, бюрократії; духовність, відкритість, етичність у своєму органічному поєднані забезпечують високий рівень самоорганізації особистості, щирість почуттів, думок, стосунків, суголосність морально-етичних норм, що відповідають канонам професійної етики, традиціям певних соціальних груп; саморефлексія, самоаналіз, саморозвиток - синтезують свідоме ставлення до власної поведінки в конфліктні та аналіз свого ставлення до прагнень, почуттів, інтересів його учасників. Це стимулює переосмислення старих стереотипів, пізнання нового, прагнення до навчання і самовдосконалення.

3'ясовуючи блок професійних характеристик, акцентуємо увагу на тому, що оволодіння грунтовними теоретичними знаннями про феномен педагогічного конфлікту має орієнтувати на розуміння того, що вони постійно нарощуються і модифікуються. Це передбачає плюралізм, контроверсійність, багатоаспекність, нелінійність у трактуванні терміносистеми, яка характеризує феномен педагогічного конфлікту та його структурні компоненти. За такої постановки проблеми напрацьовані за останні десятиліття методики і техніки формування конфліктологічної культури потребують перегляду і поєднання з інноваційними підходами, які відповідають принципам плюралізму, ідейної багатогранності, терпимості здобувачів освіти та педагогів.

Бачимо перспективу творчого поєднання напрацьованих у педагогічній конфліктології методів і прийомів формування конфліктологічної культури майбутніх педагогів (Гречановська, 2018; Козич, 2008; Кошечко, 2018 та ін.) з маловідомими у вітчизняному науковому та освітньому просторі західними ідеями, технологіями, досвідом. Як приклад, відзначимо концепцію «Лафронтера», що постає як уявна зона прикордоння, де співіснують різні точки зору, які вступають у конфлікт між собою та піддають сумнівам базові ідеї і принципи ідентичності, успадковані від сім’ї, системи освіти та різних / своїх культур. На цій основі утверджується постулат, згідно з яким сприйняття різних позицій робить їх більш прозорими, зрозумілими, тому конфлікти ментальностей та інтересів, що виникають на цьому грунті, сприймаються як нормальні природні явища, які лише допомагають гармонійному суспільному та особистісному розвитку (Anzaldua, 1987). Заслуговує на увагу і напрацьований Т. Гутьєрез-Шмич концепт 
«конфліктної педагогіки», що складається з постструктуралізму (орієнтує на вивчення «реальної людини», яка сформувалася у процесі соціокультурного розвитку з усіма притаманними ііі природі суперечностями); теорія квіру (передбачає усвідомлення «множинності людської сутності» та вибір різних освітніх стратегій і програм); діагностичної методики крос-кейсів (системний аналіз конфліктних ситуацій у середовищі університету на основі цілеспрямованого нагромадження емпіричного матеріалу (Gutierez-Schmich, 2016, p. 32-41).

Висновки. Отже, представлені в статті ідеї, підходи, положення дають змогу стверджувати, що у формуванні конфліктологічної компетентності майбутніх фахівців назріла потреба зміни пріоритетів: замість зосередження основних зусиль на запобіганні й попередженні виникненню конфліктів вони у своїй майбутній професійній діяльності мають першочергову увагу приділяти випрацюванню в здобувачів освіти продуктивного досвіду поведінки в конфлікті. Це передбачає зміну уявлень про природу конфлікту, які не є «злом апріорі», а об'єктивно зумовленим компонентом освітнього процесу і соціальних стосунків. Зважаючи на це, мають удосконалюватися особистісний та професійний компоненти педагогічної майстерності.

Предметом подальших досліджень має стати цілеспрямована розробка теоретичних ідей, положень та оригінальних методик і технологій, які сприятимуть формуванню конфліктологічної компетентності майбутніх фахівців в обгрунтованому нами ракурсі.

\section{СПИСОК ВИКОРИСТАНОЇ ЛІТЕРАТУРИ}

Gutierez-Schmich, T. (2016). Public Pedagogy and Conflict Pedagogy: Sites of Possibility for Anti-Oppressive Teacher Education. A dissertation Presented to the Department of Education Studies and the Graduate School of the University of Oregon in partial fulfillment of the requirements for the degree of Doctor of Philosophy. 293 p. URL: https://scholarsbank.uoregon.edu > GutierezSchmich (дата звернення: 20.04.2021).

Гречановська, О. В. (2018). Педагогічна система формування конфліктологічної культури в майбутніх фахівців технічних спеціальностей: монографія. Вінниця: ТОВ «ТВОРИ». $440 \mathrm{c.}$

Козич, І. В. (2008). Формування конфліктологічної компетентності соціального педагога в умовах магістратури: дис. ... канд. пед. наук: 13.00.05. Запоріжжя, $254 \mathrm{c}$.

Хасан, Б. И. (2003). Конструктивная психология конфликта. Санкт-Петербург: Питер, 250 с.

Капченко, О. Л. (2015). Дефініція педагогічної майстерності. URL: https://www.narodnaosvita.kiev.ua (дата звернення: 22.03.2021).

Кузьменко, Ю. В. (2018). Поняття «педагогічна майстерність» у науково-педагогічному дискурсі. Педагогічний альманах. Вип. 37. С. 113-118.

Педагогічна майстерність: підручник. (2008) / за ред. І. А. Зязюна. Київ: СПД Богданова. 376 с.
Кошечко, Н. В. (2018). Інноваційні технології навчання студентів з педагогічної конфліктології. Вісник Киїського національного університету імені Тараса Шевченка. Серія «Педагогіка». Вип. 1. С. 32-37.

Anzaldua, G. (1987). Borderlands / Lafrontera: The new mestiza. San Francisco: Aunt LuteBooks. 201 p. URL: http://users.uoa.gr > (дата звернення 21.02.2021).

\section{REFERENCES}

Gutierez-Schmich, T. (2016). Public Pedagogy and Conflict Pedagogy: Sites of Possibility for Anti-Oppressive Teacher Education. A dissertation Presented to the Department of Education Studies and the Graduate School of the University of Oregon in partial fulfillment of the requirements for the degree of Doctor of Philosophy. 293 p. URL: https://scholarsbank.uoregon.edu > GutierezSchmich (data zvernennia: 20.04.2021). [in English].

Hrechanovska, O. V. (2018). Pedahohichna systema formuvannia konfliktolohichnoi kultury v maibutnikh fakhivtsiv tekhnichnykh spetsialnostei [Pedagogical system of formation of conflict culture in future specialists of technical specialties]: monohrafiia. Vinnytsia: TOV «TVORY». 440 s. [in Ukrainian].

Kozych, I. V. (2008). Formuvannia konfliktolohichnoi kompetentnosti sotsialnoho pedahoha $\mathrm{v}$ umovakh mahistratury [Formation of conflictological competence of the social teacher in the conditions of a magistracy]: dys. ... kand. ped. nauk: 13.00.05. Zaporizhzhia, 254 s. [in Ukrainian].

Khasan, B. Y. (2003). Konstruktyvnaia psykholohyia konflykta [Constructive psychology of conflict]. SPb: Pyter, $250 \mathrm{~s}$. [in Russian].

Kapchenko, O. L. (2015). Definitsiia pedahohichnoi maisternosti [Definition of pedagogical skills]. URL: https://www.narodnaosvita.kiev.ua (data zvernennia: 22.03.2021). [in Ukrainian].

Kuzmenko, Yu. V. (2018). Poniattia «pedahohichna maisternist» u naukovo-pedahohichnomu dyskursi [The concept of «pedagogical skill» in scientific and pedagogical discourse]. Pedahohichnyi almanakh. Vyp. 37. S. 113-118. [in Ukrainian].

Pedahohichna maisternist (2008) [Pedagogical skill]: pidruchnyk / za red. I. A. Ziaziuna. Kyiv: SPD Bohdanova. 376 s. [in Ukrainian].

Koshechko, N. V. (2018). Innovatsiini tekhnolohii navchannia studentiv z pedahohichnoi konfliktolohii [Innovative technologies of teaching students in pedagogical conflictology]. Visnyk Kyivskoho natsionalnoho universytetu imeni Tarasa Shevchenka. Seriia «Pedahohika». Vyp. 1. S. 32-37. [in Ukrainian].

Anzaldúa, G. (1987). Borderlands / Lafrontera: The new mestiza. San Francisco: Aunt LuteBooks. 201 p. URL: http://users.uoa.gr > (data zvernennia: 21.02.2021). [in English].

Дата надходження до редакиіï: 06.08.2021 p. 